\title{
Parasitic profile of traction equids in the semi-arid climate of Paraíba State, Northeastern, Brazil
}

\author{
Perfil parasitário de equídeos de tração em clima semiárido do Estado da Paraíba, Nordeste do Brasil \\ Paulo Wbiratan Lopes da Costa ${ }^{1}$; Vinícius Longo Ribeiro Vilela ${ }^{1,2^{*}}$; Thais Ferreira Feitosa ${ }^{2}$ \\ ${ }^{1}$ Programa de Pós-graduaçáo em Zootecnia, Universidade Federal de Campina Grande - UFCG, Patos, PB, Brasil \\ ${ }^{2}$ Departamento de Medicina Veterinária, Instituto Federal da Paraíba - IFPB, Sousa, PB, Brasil
}

Received July 15, 2017

Accepted April 3, 2018

\begin{abstract}
The objective of this study was to determine the parasitological profiles of traction equids from the semi-arid climate of Paraíba (PB) State. We analyzed 96 equids that performed traction work, with no defined breed, males and females, and all older than 24 months. Among the analyzed animals, 51\% were donkeys, 41.7\% mules, and 7.3\% horses. Fecal material and blood were collected for parasitological examination and to determine the packed cell volume (PCV), respectively. The samples were sent to the Veterinary Parasitology Laboratory, Veterinary Hospital - IFPB, Sousa-PB campus, and epidemiological questionnaires were provided to the owners. It was observed that $83.3 \%$ of equids tested positive for gastrointestinal parasites. Strongylidae was the most prevalent parasite (83.3\%), followed by Giardia sp. (5.3\%), and Eimeria sp. (2.1\%). The mean eggs per gram (EPG) value of the fecal samples was 1143 . Fecal analysis revealed that $78.9 \%$ of the larvae were from "small strongyles". The presence of ectoparasites was not observed in the studied animals. The answers to our questionnaire revealed that $69.8 \%$ of the animals had never been dewormed and that the remaining $31.2 \%$ had only been dewormed once. We concluded that the prevalence of gastrointestinal parasites among traction equids in the municipality of Sousa-PB is high.
\end{abstract}

Keywords: Traction animals, donkeys, horses, mules, parasitism, cyatosthome.

\section{Resumo}

Objetivou-se determinar o perfil parasitológico de equídeos carroceiros no município de Sousa, Sertão da Paraíba. Foram analisados 96 equídeos que realizavam trabalho de tração, sem raça definida, machos e fêmeas, idade superior a 24 meses. Dentre os animais analisados 51\% foram asininos, 41,7\% muares e 7,3\% equinos. Foi coletado material fecal para exames coproparasitológicos e sanguíneo para determinação do volume globular (VG), encaminhados ao Laboratório de Parasitologia Veterinária, Hospital Veterinário - IFPB, campus Sousa-PB. Foi aplicado questionários epidemiológicos aos proprietários. Observou-se que $83,3 \%$ dos equídeos carroceiros foram positivos nos exames parasitológicos fecais. Os Estrongilídeos foram os parasitos mais prevalentes (83,3\%), seguidos por Giardia sp. (5,3\%). e Eimeria sp. (2,1\%). A média de OPG dos equídeos carroceiros foi 1143. Nas coproculturas, constatou-se que 78,9\% das larvas eram de "pequenos estrôngilos". Não foi observada a presença de ectoparasitas. Em 69,8\% dos animais nunca haviam sido vermifugados e os demais 31,2\% apenas uma vez. Concluiu-se que é alta a prevalência de parasitos gastrintestinais em equídeos carroceiros do município de Sousa-PB.

Palavras-chave: Animais de tração, asininos, equinos, muares, parasitismo, ciatostomíneos.

The use of traction equids is still very common in the interior of Brazil. They are important in the generation of income for families, especially through the collection of garbage and recyclables and the transport of materials (PAZ et al., 2013). Traction equids are used mainly in developing countries and are directly linked to jobs in agriculture, trade, and transport (UPJOHN et al., 2014).

*Corresponding author: Vinícius Longo Ribeiro Vilela. Instituto Federal da Paraíba - IFPB, Av. Presidente Tancredo Neves, s/n, Jardim Sorrilândia, CEP 58800-970, Sousa, PB, Brasil. e-mail: vilelavlr@yahoo.com.br
Among the diseases that affect the health of equids, those caused by parasites stand out because of the high associated morbidity (BOTELHO et al., 2012). Infection with gastrointestinal parasites is usually subclinical, resulting in significant losses in animals used for reproduction, sport, and work (RIET-CORREA et al., 2001).

Infection with "small strongylus" or cyathostomines causes anemia, diarrhea, and reduced nutrient absorption, causing weight loss and decreased productivity (MOLENTO, 2005). The large strongyles are hematophagous parasites that are found 
in the mucosa of the cecum and colon of equids in the adult phase (VAN DER KOLK \& KROEZE, 2013).

Gastrointestinal protozoa such as Eimeira sp., Giardia sp., and Cryptosporidium spp. cause intermittent diarrhea, anorexia, weight loss, and brittle hair (GEURDEN et al., 2010).

The most prevalent ectoparasites in equids include the ticks Amblyomma cajennense, Anocentor nitens, and Rhipicephalus (Boophilus) microplus. Tick infestation causes economic loss due to decreasing animal productivity and the expense associated with the use of tick preventives (PRATA et al., 1996).

There are no reports that describe the main parasites of traction horses, donkeys, and mules in the municipality of Sousa-PB. Therefore, the objective of this study was to identify the main parasites in working equids in the municipality of Sousa, arid midland of Paraíba.

This study was performed in the municipality of Sousa, Paraíba. The laboratory analyses were performed at the Veterinary Parasitology Laboratory (LPV), Veterinary Hospital, Federal Institute of Education Science and Technology of Paraíba (IFPB), Sousa-PB campus.

The number of animals required for analysis was calculated using an expected prevalence of 50\% for gastrointestinal helminths, gastrointestinal protozoa, and ectoparasites since there are no previous reports detailing the prevalence of these parasites in equids in the semi-arid region of Paraíba. A minimum confidence level of $95 \%$ was also considered assuming a statistical error of $10 \%$ (THRUSFIELD, 1995).

For the identification of helminths and protozoa in the equids, fecal samples were collected as advised by Gordon \& Whitlock (1939). Fecal analysis was performed in accordance with the study by Roberts \& O'Sullivan (1950), and the eggs per gram of feces (EPG) were calculated for each parasitic helminth. Centrifugation in Sucrose Solution (CFSS), the method developed by Tobie et al. (1938), was used to isolate protozoal cysts and oocysts as well as low-density eggs. For the quantification and identification of the larvae isolated in the fecal examinations, the method of Bevilaqua et al. (1993) was followed. To identify ectoparasites, inspection of the entire body of the animal was performed. For the determination of the PCV using the microhematocrit method (FERREIRA et al., 1978), blood samples were collected by jugular venipuncture into a tube containing EDTA anticoagulant (10\%) and then sent to LPV.

An epidemiological questionnaire was provided to the owners of the traction equids, in which the cleanliness and nutrition of the animals were addressed. The following information was requested: owner's and animal's signalment, management of the animal (nutrition and sanitation), and health history of the animal.

The data were analyzed using the chi-square test, followed by the Fisher's exact test at a $5 \%$ level of significance (SERRA-FREIRE, 2002).

We analyzed 96 equids that performed traction work in the municipality of Sousa-PB, with no defined breed, of both sexes, and of at least twenty-four months of age. Among the equids analyzed, 51\% (49/96) were donkeys, 41.7\% (40/96) mules, and $7.3 \%$ (7/96) horses.

It was observed that $83.3 \%(80 / 96)$ of the traction equids had positive fecal parasitological examinations. Piccoli et al. (2015) also detected a high prevalence of parasitic infection (82\%) among traction horses in Porto Alegre, Rio Grande do Sul. Ferraro et al. (2008) likewise identified a parasitological prevalence of $88 \%$ among traction horses in Curitiba, Paraná.

There was no statistically significant difference $(p \geq 0.05)$ in the prevalence of gastrointestinal parasites among the species evaluated (Table 1).

Strongylidae were the most prevalent parasites (83.3\%), followed by Giardia sp. (5.3\%), and Eimeria sp. (2.1\%). Infection with Strongylidae was also found to be common (96.03\%) in traction and leisure horses in Porto Alegre, RS (PICCOLI et al., 2015).

In the present work $5.3 \%(5 / 96)$ of the animals were positive for Giardia sp. and 2.1\% (2/96) were positive for Eimeria sp. A similar prevalence for the genus Giardia (4\%, 6/150) was found by Nasciutti et al. (2013) in a slaughterhouse in the city of Araguari, Minas Gerais.

An association was observed between Strongylidae and the protozoa Giardia sp. in 8.2\% (4/49) of the donkeys. Among the mules, 5\% (2/40) were positive for the protozoa Eimeria sp. in combination with Strongylidae. Among the horses, 14.3\% (1/7) had an association between Strongylidae and Giardia sp. In a study performed by Souza et al. (2009) on horses in Rio de Janeiro-RJ, an association was detected between Giardia sp. and Eimeria sp. This differed from the present study, in which no animal showed infection with more than one genus of protozoa.

It was observed that $85.7 \%$ of the male equids and $80 \%$ of the females were infected with gastrointestinal parasites. However, only among the horses was the difference between the sexes statistically significant $(p \leq 0.05)$ (Table 2$)$. However, low sampling of male horses may have interfered with the results and promoted this difference.

The mean $( \pm$ SD) EPG of the traction equids was $1143( \pm 1853)$. The donkeys possessed a statistically lower mean EPG $(p \leq 0.05)$ as compared to the other species at $807( \pm 770)$, whereas the mule EPG average was $1571( \pm 2682)$ and the horses was $1050( \pm 800)$. On classifying by category, 35\% (34/96) of the animals were classified as having low-level infection (<500), 28\% (27/96) as medium (500-1000), and 37\% (35/96) as high (>1000). The donkeys possessed the highest percentage of positive fecal examinations but the lowest level of parasitic disease, confirming the resistance of the species. Chitra et al. (2011) stated that, although donkeys are also known in India for their robustness, they are the species most vulnerable to parasitic infection.

Only among the horses did the prevalence of infection differ significantly $(p \leq 0.05)$ between the females and the males. In general for the traction equids, there was no statistically significant difference $(p \geq 0.05)$ in EPG between the sexes (Table 3). Similar results

Table 1. Number of infected animals and prevalence (\%) of helminths and protozoa among traction equids in Sousa, Paraíba, Brazil.

\begin{tabular}{lcccc}
\hline \multicolumn{1}{c}{ Species } & Total & Strongylidae & Giardia sp. & Eimeria sp. \\
\hline Donkey & 49 & $42(85.7)$ & $4(8.2)$ & - \\
Mule & 40 & $33(82.5)$ & - & $2(5)$ \\
Horse & 7 & $5(71.4)$ & $1(14.3)$ & - \\
$\begin{array}{l}\text { Number of } \\
\text { animals }\end{array}$ & 96 & $80(83.3)$ & $5(5.3)$ & $2(2.1)$ \\
\hline
\end{tabular}


Table 2. Prevalence of helminths and protozoa among traction equids, according to sex, in Sousa, Paraíba, Brazil.

\begin{tabular}{|c|c|c|c|c|c|c|}
\hline \multirow{2}{*}{ Species } & \multirow{2}{*}{ Sex } & \multirow{2}{*}{ Total } & \multirow{2}{*}{ Prevalence (\%) } & \multicolumn{3}{|c|}{ Prevalence/Total (\%) } \\
\hline & & & & Strongylidae & Giardia sp. & Eimeria sp. \\
\hline \multirow[t]{2}{*}{ Donkey } & Male & 27 & $24(88.9)$ & $24 / 24(100)$ & $2 / 24(4.2)$ & - \\
\hline & Female & 22 & $18(81.8)$ & 18/18 (100) & $2 / 18(6.2)$ & - \\
\hline \multirow[t]{2}{*}{ Mule } & Male & 27 & $23(85.1)$ & $23 / 23(100)$ & - & $2 / 23(4.2)$ \\
\hline & Female & 13 & $10(77)$ & $10 / 10(100)$ & - & - \\
\hline \multirow[t]{2}{*}{ Horse } & Male & 2 & $1(50)^{*}$ & $0 / 1(0)$ & $1 / 2(50)$ & - \\
\hline & Female & 5 & $5(100)^{*}$ & $5 / 5(100)$ & - & - \\
\hline \multirow[t]{2}{*}{ Number of animals } & Male & 56 & $48(85.7)$ & 47/48 (98) & $3 / 48(6.3)$ & $2 / 48(4.2)$ \\
\hline & Female & 40 & $32(80)$ & $32 / 32(100)$ & $2 / 32(6.3)$ & - \\
\hline
\end{tabular}

Values followed by asterisks differ significantly $(\mathrm{p} \leq 0.05)$.

Table 3. Mean and standard deviation of eggs per gram (EPG) in male and female traction equids in Sousa, Paraíba, Brazil.

\begin{tabular}{ccccc}
\hline Species & Sex & Total & $\begin{array}{c}\text { Positive } \\
(\%)\end{array}$ & $\begin{array}{c}\text { EPG mean } \pm \text { standard } \\
\text { deviation }\end{array}$ \\
\hline Donkey & Male & 27 & $24(88.9)$ & $944 \pm 862$ \\
& Female & 22 & $18(81.8)$ & $638 \pm 610$ \\
Mule & Male & 27 & $23(85.1)$ & $1630 \pm 2813$ \\
& Female & 13 & $10(77)$ & $1450 \pm 2491$ \\
Horse & Male & 2 & $0(00)$ & $0 \pm 0^{*}$ \\
& Female & 5 & $5(100)$ & $1470 \pm 590^{*}$ \\
Total & Male & 56 & $48(85.7)$ & $1241 \pm 2066$ \\
& Female & 40 & $32(80)$ & $1006 \pm 1521$ \\
\hline
\end{tabular}

Values followed by asterisks differ significantly ( $\mathrm{p} \leq 0.05$ ).

were found by Ferraro et al. (2008) when evaluating traction animals from Curitiba-Paraná, where the mean EPG for males was 1,492 and that for females was 1,322 .

Mules aged $\geq 12$ years had significantly higher EPG $(p \leq 0.05)$ as compared to mules in other age groups and to other species of the same age group (Table 4). It was also observed that animals $\geq 12$ years of age were more vulnerable $(p \leq 0.05)$ to high levels of parasitism. This finding was also made by Ferraro et al. (2008) who observed an average EPG of 1438 (high level) in adult and geriatric animals. It has been shown that as they increase in age, equids develop a resistance where they may develop severe infections while remaining asymptomatic (BOWMAN, 2014). Thus, equids of advanced age become sources of infection for younger animals.

No statistically significant difference was observed $(p \geq 0.05)$ when the EPG levels were evaluated in association with the PCV (Figure 1). When evaluating gastrointestinal parasitism and hematology in horses and donkeys in São Luís, Maranhão, Ferreira et al. (2014) observed that the degree of parasitism was not responsible for the hematological alterations.

In the fecal examinations, it was found that $78.9 \%$ of the larvae were small strongyles or cyathostomes, followed by $7.1 \%$ Strongylus equinus, 3\% Strongylus edentatus, 6\% Strongylus vulgaris, and 5\% Trichostrongylus axei (Figure 2). It was observed that among the horses, $S$. vulgaris was present with the highest prevalence (12.8\%). Similar results were obtained by Ferraro et al. (2008), with an average prevalence of $88 \%$ for the cyathostomes and $12 \%$ for $S$. vulgaris.
Table 4. Relationship between mean EPG $( \pm$ SD) and the equid age range.

\begin{tabular}{lccc}
\hline \multirow{2}{*}{ Species } & \multicolumn{3}{c}{ Total (mean EPG $\pm \mathbf{S D})$} \\
\cline { 2 - 4 } & $\mathbf{2} \leq \mathbf{6}$ years & $\mathbf{6} \leq \mathbf{1 2}$ years & $>\mathbf{1 2}$ years \\
\hline Donkey & $9(850 \pm 610) \mathrm{Aa}$ & $26(717 \pm 744) \mathrm{Ab}$ & $14(1007 \pm 893) \mathrm{Ac}$ \\
Mule & $8(887 \pm 629) \mathrm{Ba}$ & $24(1304 \pm 2308) \mathrm{Ba}$ & $8(3143 \pm 4294) \mathrm{Aa}$ \\
Horse & $3(733 \pm 1270) \mathrm{Aa}$ & $2(1250 \pm 848) \mathrm{Aa}$ & $2(825 \pm 742) \mathrm{Ac}$ \\
Total & $20(848 \pm 689) \mathrm{Ba}$ & $52(1009 \pm 1666) \mathrm{Ba}$ & $24(1704 \pm 2678) \mathrm{Ab}$ \\
\hline
\end{tabular}

Values followed by distinct uppercase letters in the rows and lowercase letters in the columns differ statistically ( $\mathrm{p} \leq 0.05)$.

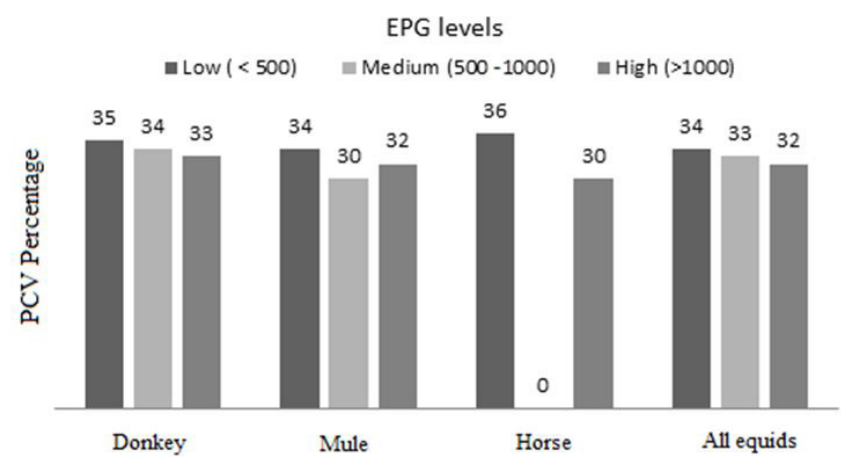

Figure 1. Packed cell volume (PCV) in relationship to the eggs per gram (EPG) levels among traction equids in Sousa, Paraíba, Brazil.

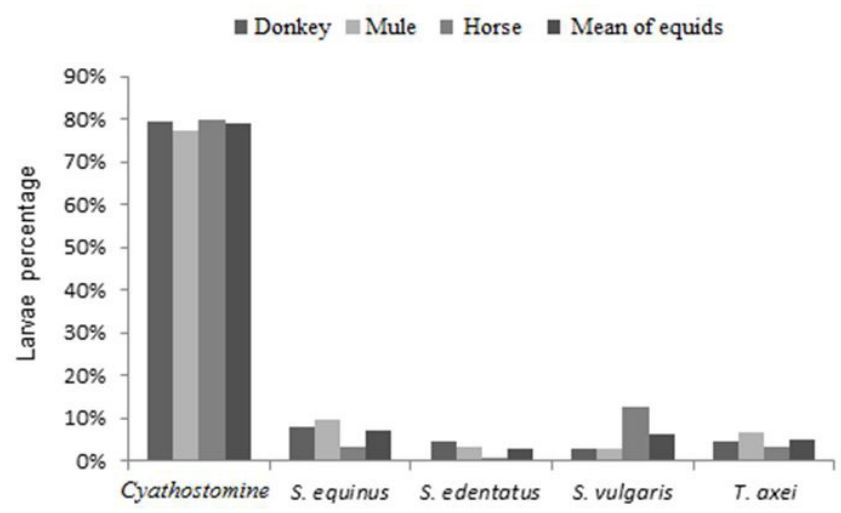

Figure 2. Percentage of gastrointestinal helminths infecting traction equids in Sousa, Paraíba, Brazil. 
Although a thorough visual inspection was performed on all animals, the presence of ectoparasites was not observed. Perhaps the rusticity of these animals, coupled with the absence of a defined breed and the high temperatures present throughout the year, does not favor ectoparasite infestation. Rego et al. (2009) also did not identify ectoparasites in 166 equines used for work and sport in Curitiba, Paraná. According to Chagas et al. (2001), high temperatures do not provide an ideal environment for the breeding and survival of engorged female ticks, and at $20^{\circ} \mathrm{C}$ the females are not very mobile. In Sousa-PB, the average annual temperature is $27{ }^{\circ} \mathrm{C}$, and the average daytime temperature exceeds $35^{\circ} \mathrm{C}$. By contrast, in Curitiba-PR, the average annual temperature does not exceed $17.5^{\circ} \mathrm{C}$ (IBGE, 2010).

In the epidemiological questionnaire, 63.5\% (61/96) of the owners replied that they possessed other equids in addition to the evaluated animal, and $60.4 \%(58 / 96)$ of the equids were maintained in direct contact with other species of animals. These included canines, felines, poultry, cattle, sheep, goats, and pigs.

Regarding the use of dewormers, $69.8 \%$ (67/96) of the equids had never been dewormed and the remaining 31.2\% (29/96) had only been dewormed once. Of the dewormers used, the only compound cited was ivermectin. The most commonly used formulation was paste $(51.7 \%, 15 / 29)$, followed by injectable $(48.3 \%, 14 / 29)$. The limited use of dewormers may explain the high parasite burden found in this study, where it was observed that 65\% (62/96) of the animals possessed EPG > 500 (medium to high).

None of the equids evaluated had been vaccinated. Furthermore, the term "vaccinated" was frequently confused with "dewormed", which denotes a low level of knowledge regarding animal health management possessed by the owners.

With regard to nutrition, 59.5\% (57/96) of the equids in this study were fed a combination of grass and corn, $37.5 \%(36 / 96)$ were pasture-fed only, and 3\% (3/96) were provided a mixture of pasture and a commercial ration. It is well known that little attention is paid to the quality of the food provided to traction equids. This may be one of the factors contributing to the high prevalence of parasitism observed in the present study. It has been proven that a well-balanced diet can improve the immune response of the host, and therefore limit the development of parasitic infections.

Inadequate nutrition and sanitation was observed in a study by Herd (1990). According to the investigators in that study, forced labor, malnutrition, and stress were associated with parasitism, and severely impaired the health of the equids, even leading to death. However, despite being used all day for work under adverse environmental conditions, the traction equids in this study were resistant to parasitic disease. No affliction was reported that required removal of any of the equids from work.

We concluded that the prevalence of gastrointestinal parasites in traction equids in the municipality of Sousa-PB is high. However, no animal presented parasitic disease. Ectoparasites were not founded on the animals in this study. Increased awareness is required for owners to improve the cleanliness of these animals.

\section{References}

Bevilaqua CML, Rodrigues ML, Cocordet D. Identification of infective larvae of some common nematode strongylids of horses. Rev Méd Vét 1993; 144(12): 989-995.

Botelho GG, Cassiano ALV, Botelho CFM, Botelho CFM. Análise hematológica, bioquímico-sérica e coproparasitológica de equinos criados em Seropédica, RJ. Rev Bras Med Vet 2012; 34(1): 69-72.

Bowman DD. Georgis' parasitology for veterinarians. 10th ed. Philadelphia: Saunders; 2014.

Brazilian Institute of Geography and Statistics - IBGE [online]. 2010 [cited 2017 Feb 13]. Available from: https://www.ibge.gov.br/

Chagas ACS, Furlong J, Nascimento CB. Behavior and ecology of engorged females of the tick, Boophilus microplus in pastures of the grass, Brachiaria decumbens in Brazil. Braz J Vet Res Anim Sci 2001; 38(4): 188-191.

Chitra R, Rajendran S, Prasanna D, Kirubakaran A. Influences of age on the prevalence of parasitic infections among donkeys in Erode district, Tamilnadu, India. Vet World 2011; 4(6): 258-259. http://dx.doi. org/10.5455/vetworld.4.258.

Ferraro CC, Kloss AB, Souza DF, Deconto I, Biondo AW, Molento MB. Parasitological prevalence of cart-horses in Curitiba, Paraná. Rev Bras Parasitol Vet 2008;17(1 Suppl 1): 175-177. PMid:20059842.

Ferreira GMS, Dutra FAF, Amorim EF Fo, Santos ACG. Gastrointestinal parasitism and hematology in horses and donkeys from the urban area of São Luís/MA, Northeast Brazil. Arch Vet Sci 2014; 19(2): 22-30.

Ferreira JM No, Viana ES, Magalhães LM. Patologia clínica veterinária. Belo Horizonte: Rabelo and Brazil; 1978.

Geurden T, Vercruysse J, Claerebout E. Is Giardia a significant pathogen in production animals? Exp Parasitol 2010; 124(1): 98-106. http://dx.doi. org/10.1016/j.exppara.2009.03.001. PMid:19285075.

Gordon HM, Whitlock HV. A new technique for counting nematode eggs in sheep faeces. J Counc Sci Ind Res 1939; 12(1): 50-52.

Herd RP. Equine parasite control-solutions to anthelmintic associated problems. Equine Vet Educ 1990; 2(2): 86-91. http://dx.doi. org/10.1111/j.2042-3292.1990.tb01396.x.

Molento MB. Parasite resistance on helminths of equids and management proposal's. Cienc Rural 2005; 35(6): 1469-1477. http://dx.doi.org/10.1590/ S0103-84782005000600041.

Nasciutti NR, Cabral DD, Cabral AD, Souza RR, Oliveira PM. Frequency of occurrence of Giardia sp. and Cryptosporidium spp. in equidae naturally infected and slaughtered in a slaughter house. Cienc Anim Bras 2013; 14(2): 253-257.

Paz CFR, Paganela JC, Oliveira DP, Feijó LS, Nogueira CEW. Biometric standard of traction horses in Pelotas, state of Rio Grande do Sul. Ciênc Anim 2013; 14(2): 159-163.

Piccoli C, Marques SMT, Appel G, Silveira E, Siqueira GB, Loos DE, et al. Helmintos intestinais em cavalos de trabalho e de lazer de Porto Alegre/ RS. Sci Anim Health 2015; 3(1): 56-64.

Prata MCA, Alonso LS, Sanavria A. Parâmetros biológicos do estádio ninfal de Amblyomm cajennense (Fabricius, 1787) (Acari: Ixodidae) em coelhos. Rev Bras Cienc Vet 1996; 3(2): 55-57. http://dx.doi.org/10.4322/ rbcv.2015.045. 
Rego DX, Schmeil BRP, Schiller JW, Silva MM, Ramos CG, Michelotto PV Jr. Incidence of endoparasites and ectoparasites in equines from the city of Curitiba - Paraná. Rev Acad Cien Agrar Amb 2009; 7(3): 281-287.

Riet-Correa F, Schild AL, Méndez MC, Lemos RAA. Doenças de ruminantes e equinos. 2nd ed. Sáo Paulo: Varela; 2001.

Roberts FHS, O'Sullivan JP. Methods of egg cougars and laval cultures for strongyles infesting the gastrointestinal tract of cattle. Aust Agric Res 1950; 1(1): 99-102. http://dx.doi.org/10.1071/AR9500099.

Serra-Freire NM. Planejamento e análise de pesquisas parasitológicas. Niterói: Publisher of Fluminense Federal University; 2002.

Souza PN, Bomfim TC, Huber F, Abboud LC, Gomes RS. Natural infection by Cryptosporidium sp., Giardia sp. And Eimeria leuckarti in three groups of equines with different handlings in Rio de Janeiro, Brazil.
Vet Parasitol 2009; 160(3-4): 327-333. http://dx.doi.org/10.1016/j. vetpar.2008.10.103. PMid:19117684.

Thrusfield M. Veterinary epidemiology. 2nd ed. Cambridge: Blackwell Science; 1995.

Tobie J, Thomen LF, Sawitz W, D’Antoni JS, Peres C, Faust EC, et al. A critical study of clinical laboratory technics for the diagnosis of protozoan cysts and helminth eggs in feces 1. Am J Trop Med Hyg 1938; s1-18(2): 169-183. http://dx.doi.org/10.4269/ajtmh.1938.s1-18.169.

Upjohn MM, Pfeiffer DU, Verheyen KL. Helping working Equidae and their owners in developing countries: monitoring and evaluation of evidence-based interventions. Vet J 2014; 199(2): 210-216. http:// dx.doi.org/10.1016/j.tvjl.2013.09.065. PMid:24269105.

Van Der Kolk JH, Kroeze EJBV. Infectious diseases of the horse: diagnosis, pathology, management, and public health. London: Manson Publishing; 2013. 